\title{
Evaluation of the Fibre-Clad Type Lead-acid Cells
}

\author{
Shigeo Hisano \\ Railway Technical Research Institute, Kokubunji-machi, Kitatama-gun, Tokyo \\ Received Dec. 29, 1963
}

\begin{abstract}
Tests have been performed for ten years off and on and the life of the fibre-clad type cells was examined both in the laboratory and in the field to compare them with the traditional pasted type cells. As the result, quite contradictory data were obtained. The larger capacity and the longer life were confirmed in the laboratory tests, but the service test for train-lighting produced somewhat negative results.

The reason of this contradiction was sought. The large capacity is not the essential factor to the cell; the results depend upon the construction of the reference cell. The long life may be explained as follows: The discharge conditions influence in different ways upon the construction of each type cell. Concretely speaking, fibre-clad type cell is, from its peculiar construction, durable for deep discharge, but the pasted one is not. For low discharge both type cells are durable as well.

The fibre-clad type cell was evaluated, taking into consideration the cost of each type cell. It is concluded that this type cell should be used only for deep discharge uses like a tractor hauling a train of trailers, a battery locomotive, etc., and not for low discharge uses like a train.
\end{abstract}

\section{Introduction}

About ten years have elasped since the fibreclad type cell was produced by a manufacturer and appeared on the market in Japan with a sensational announcement that both its capacity and life are far superior to those of the traditional pasted type i.e. the capacity is $20 \%$ larger and the life is twice or more longer.

In the Railway Technical Research Institute of the Japanese National Railways, much interest has been laid on this cell since the early period of its manufacture. Test on this new cell have been continued up to present in comparison with the pasted type cells. The results are summarized as follows: The results of the laboratory cycle tests, which were carried out twice and further twice including the cells of other manufacturers who later started the production under somewhat different discharge conditions endorsed the boastful annourcement. However, the results of service tests for train-lighting were disappointing. There was no alleged superiority of the fibre-clad type cell to the pasted one both in capacity and life and the only thing that distinguishes the former from the latter is its $30 \%$ higher cost.

Considerations upon these opposed results were given and it was concluded that the influence of discharge conditions appeared in different ways according to differnt construction of each type cell. This was further confirmed by a supplemental service test conducted on a tractor which hauls a train of trailers.

The evaluation of the fibre-clad type cell was made upon these data with some economic considerations.

\section{Laboratory Tests}

\subsection{Cells Used}

(1) Outline of test and reference cells, shown in Table 1.

(2) Construction and characteristics of cells

For the convenience of laboratory tests, cells for each test were assembled with a few plates in such a way that was specified in Japanese Indutrial Standard or Japanese Railway Standard with some modifications of the parts and with fundamental factors as they are. Reference cells were assembled corresponding to the test cells. Summary of the construction is shown in 
Table 1 Year of Manufacture, Manufacturer and Characteristics of Construction

\begin{tabular}{|c|c|c|c|}
\hline \multirow[b]{2}{*}{ Test } & \multirow{2}{*}{$\begin{array}{c}\text { Year of } \\
\text { manufacture }\end{array}$} & \multicolumn{2}{|c|}{ Characteristics of cell, manufacturer } \\
\hline & & Test cells (Fibre-clad) & $\begin{array}{l}\text { Reference cells } \\
\text { (Pasted, vibration-proof) }\end{array}$ \\
\hline TL 1 & 1951 & \multirow{2}{*}{$\begin{array}{l}\text { Matted glass fibre reinforced with synthetic } \\
\text { resin by manufacturer A }\end{array}$} & \multirow[t]{2}{*}{ Manufacturer A } \\
\hline TL 2 & 1953 & & \\
\hline TL 3 & 1953 & \multirow{2}{*}{$\begin{array}{l}\text { Matted tube by manufacturers } \mathrm{A}, \mathrm{B} \text {. Braided } \\
\text { glass fibre tube by manufacturers } \mathrm{C}, \mathrm{D}, \mathrm{E} \text {. }\end{array}$} & Manufacturer A, B, C, D \\
\hline TL 4 & 1960 & & Manufacturer $\mathrm{E}$ \\
\hline
\end{tabular}

Table 2 Construction and Characteristics of Cells

\begin{tabular}{|c|c|c|c|c|}
\hline \multicolumn{2}{|l|}{ Cell } & TL 1 , TL 2 & TL 3 & TL 4 \\
\hline \multirow[t]{2}{*}{ Test } & Model & \multicolumn{2}{|c|}{$\begin{array}{l}\text { VEM } 5 \\
\text { (ebonite-clad type with the capacity of } 115 \text { Ah in } 5 \mathrm{HR} \text { ) } \\
\text { prescribed in Japanese Industrial Standard in } 1952 \text { which } \\
\text { passed in those days of tests. }\end{array}$} & $\begin{array}{l}\text { TRH } 10 \\
\text { (Fibre-clad type with the } \\
\text { capacity of } 320 \mathrm{~A} \text { ) pre- } \\
\text { scribed in Japanese Rail- } \\
\text { way Standard. }\end{array}$ \\
\hline & Points altered & $\begin{array}{l}\text { Positive plates are lessened } \\
\text { from } 5 \text { to } 2 \text { A plate is } \\
\text { composed of } 15 \text { tubes with } \\
\text { a diameter of } 9.6 \mathrm{~mm} \text {. }\end{array}$ & $\begin{array}{l}\text { Positive plates are lessened } \\
\text { from } 5 \text { to } 1 . \text { One tube was } \\
\text { lessened : from } 15 \text { to } 14 .\end{array}$ & $\begin{array}{l}\text { Positive plates are lessened } \\
\text { from } 10 \text { to } 1 \text { A plate is } \\
\text { composed of } 14 \text { tubes with } \\
\text { a diameter of } 10 \mathrm{~mm} \text {. }\end{array}$ \\
\hline \multirow[t]{2}{*}{ Reference } & Model & $\begin{array}{l}\text { VGAM } 5 \\
\text { (Vibration-proof construc- } \\
\text { tion with glass mats,capac- } \\
\text { ity of } 115 \text { Ah in } 5 \mathrm{HR} \text { ) } \\
\text { prescribed in JIS. }\end{array}$ & $\begin{array}{l}\text { TRE } 16 \\
\text { (Vibration-proof construc- } \\
\text { tion with glass mats, capa- } \\
\text { city of } 320 \text { Ah in } 5 \mathrm{HR} \text { ) } \\
\text { prescribed in JRS. }\end{array}$ & $\begin{array}{l}\text { TRA } 12 \\
\text { (Vibration-proof construc- } \\
\text { tion with glass mats, capa- } \\
\text { city of } 320 \text { Ah in } 5 \mathrm{HR} \text { ) } \\
\text { prescribed in JRS. }\end{array}$ \\
\hline & Points altered & $\begin{array}{l}\text { Positive plates are lessened } \\
5 \text { to } 2 ; 5 \mathrm{~mm} \text { in thickness }\end{array}$ & $\begin{array}{l}\text { Positive plates are lessened } \\
\text { from } 16 \text { to } 2 ; 3 \mathrm{~mm} \text { in } \\
\text { thickness }\end{array}$ & $\begin{array}{l}\text { Positive plates are lessened } \\
\text { from } 12 \text { to } 1 ; 5 \mathrm{~mm} \text { in } \\
\text { thickness }\end{array}$ \\
\hline
\end{tabular}

Table 2. Each element of test TL 1, TL 2 and TL 3 was suspended by two bars made for the purpose on the top edge of the ebonite jar with an inside dimension of $148 \times 73 \times 344 \mathrm{~mm}$, and fixed. In TL 1, TL 2 and TL 3, each element of the reference cell was especially designed so as to keep the side pressure $20 \mathrm{~kg} / \mathrm{dm}^{2}$. In TL 4 , the sideboards of adequate thickness were inserted into the gap between the outside negative plates and the inside wall of the jar for the purpose of keeping the side pressure and the amount of electrolyte approximately equal to the specified conditions.

\subsection{Method of the Test}

\section{(1) General}

Two of each kind of cells were connected in series and the test was performed under the same conditions. The capacity was tested three times at the start of each life test in a water bath at a temperature of $40 \pm 1 \mathrm{C}^{\circ}$. The capacity was indicated by the length of time in hours required for the cell voltage to reach a final terminal voltage equivalent to $1.7 \mathrm{~V}$, with the exception of $1.6 \mathrm{~V}$ in the fibre-clad cell type in TL 3 while discharging at the current shown in Table 3.

The cycle test consisted of an automatic one hour discharge and a two hour charge each at the current shown in Table 3. The electrolyte temperature during the cycle test was always kept at the above-mentioned value. The capacity was further tested once at every 100 cycles under

Table 3 Capacity of Reference Cell, Current of Charge and Discharge

\begin{tabular}{c|c|c|c}
\hline \hline Test & $\begin{array}{c}\text { Capacity* } \\
\text { (Ah in 5 HR) }\end{array}$ & $\begin{array}{l}\text { Discharge Cur- } \\
\text { rent (A) }\end{array}$ & $\begin{array}{c}\text { Charge Current } \\
\text { (A) }\end{array}$ \\
\hline TL 1 & 50 & 20 & 13 \\
TL 2 & 50 & 32 & 21 \\
TL 3 & 40 & 20 & 13 \\
TL 4 & 27 & 20 & 13 \\
\hline
\end{tabular}

* Each value was calculated from the specified capacity of the reference cells in accordance with the changed number of plates. 
the same conditions as mentioned above.

\section{(2) Characteristics of each test}

TL 1 was performed on a test cell whose capacity was much larger than that of the reference cell. This is because the capacity of the test cell was supposed to correspond to that of the ebonite-clad type cell (VEM 5) which is specified to be equal to the reference cell of the pasted type cell (VGAM 5). In TL 2, one tube was lessened from each plate of test cells to reduce the capacity, and the discharging current was increased in order to get the test results in shorter time. In TL 3 , the relatively large capacity of test cells was approximately corrected by lessening the number of positive plates of test cells from 2 to 1 and using two $3 \mathrm{~mm}$ thick positive plates for the reference cell. TL 4 was made on the products of four manufacturers which were presented seven years after TL 3 . Improvements had been made on several faults by manufacturers in these years*. This test was performed with the relatively large capacity left as it was for another purpose of getting the comparative data in life between cells TRH 10 and TRA 12 , both of which were specified by JRS (Table 2) a little while ago.

\subsection{Results}

The capacity obtained in the third test is shown in Figs. 1 to 4, which is the value of 1 st cycle. The life in each test is indicated on the life curves of Figs. 1 to 4 . In Figs. 3 and 4 , the capacity and the life are shown by the mean value of the two cells. In Fig. 1 test cells are nearly 35\% larger in capacity and 66\% larger in life than ordinary paste-type cells. The results on the life, however, may include some inaccuracy due to the larger capacity of the test cell. In Fig. 2, notwithstanding the approach of the capacity to that of the reference cells, the superiority of the fibre-clad type cell in life becomes more conspicuous than expected. From

\footnotetext{
* The upper bar is covered by a molded plastic. The bottom bar is replaced by a molded plastic bar making a pressed fit to the end of each spin. The sleeve of manufacturer $B$ was reinforced by a thread of a spiral included inside of it. Anticorrosion materials of the spin, the form of the spin, the construction at the end of the sleeve were also improved.
}

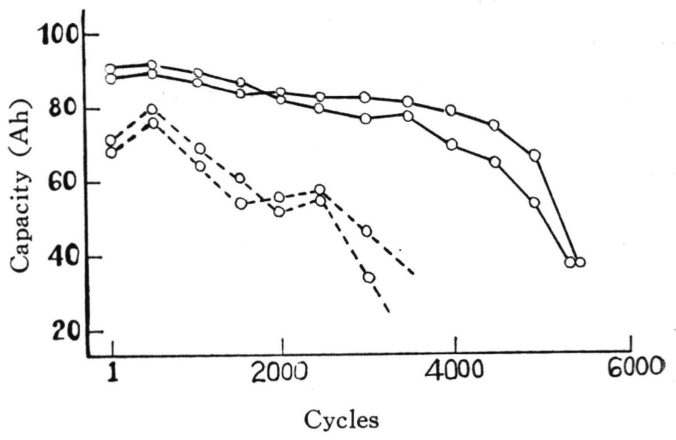

- - Fibre-clad cell $\quad-\bigcirc--$ Pasted cell Discharge $20 \mathrm{~A} \times 1 \mathrm{~h} \quad$ Charge $13 \mathrm{~A} \times 2 \mathrm{~h}$

Temperature $40 \pm 1^{\circ} \mathrm{C}$

Fig. 1 The life of the fibre-clad type cells and the pasted one in Laboratory tests.

(a) Products in 1951 by manufacturer A

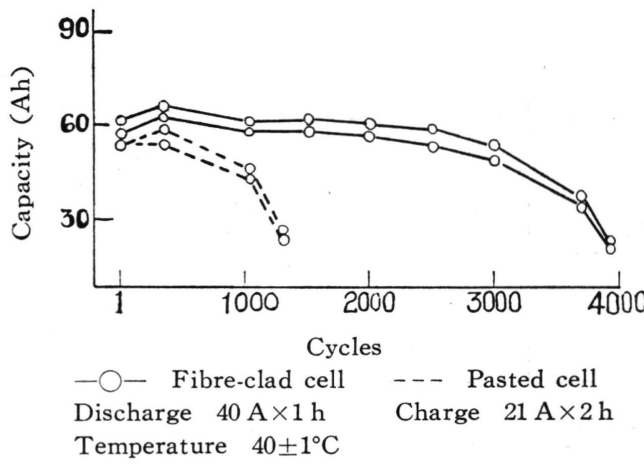

Fig. 2 The life of the fibre-clad type cells and the pasted one in laboratory test.

(b) Products in 1953 by manufacturer A

Fig. 3 it can be seen that for every manufacturers the life of test cells is about twice longer than that of the reference cell. From this result, the longer life of the fibre-clad type cell is confirmed to be universally relaible. In Fig. 4 the curve of the reference cell was corrected approximately $20 \%$ by increasing both in capacity and life. The longer life of test cells is recognized as a result of a remarkable improvement, which was especially observed on the cell of manufacturer $\mathrm{B}$ but a deterioration was observed on one of manufacturer A. From Figs. 3 and 4 , it is difficult to draw conclusions on the matted and the braided tubes.

\subsection{Considerations}

The larger capacity of the fibre-clad type cells shown in TL 1 is undoubtedly obtained by the 


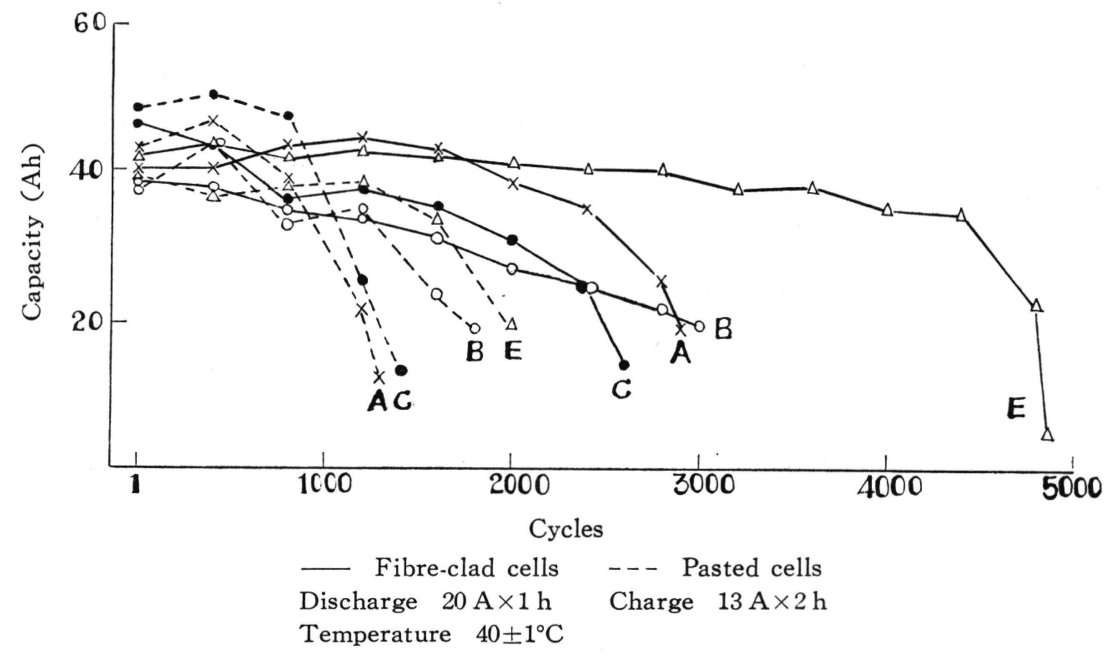

Fig. 3 The life of the fibre-clad type cells and the pasted one in Laboratory tests.

(c) Products in 1953 by four manufactures

alteration of the material of tubes from ebonite to glass fibre because both type cells of VEM 5 and VGAM 5 are so specified as to have an equal capacity. Great superiority of the fibreclad type cell to the pasted one in life as observed on TL 2 is worthy of note. This is considered to be due to the effects of discharge conditions, especially of the deepness of discharge upon its peculiar construction, and not due to the plates because those belong to the same manufacturing processes as shown in Fig. 1. Upon this problem, further consideration will be given afterwards. The results of TL 3 performed under the balance of capacity with the reference cells on the products of all manufacturers lead, together with the results of TL 1 and TL 2, to the final conclusion universally confirming the latter part of the above-mentioned statement that the life of the fibre-clad type cell is twice or more longer than that of the pasted type. In Fig. 4, the short life of the cell of the manufacturer $\mathrm{A}$ is shown notwithstanding the long life of the cell shown in Figs. 1 and 2, but this is caused by the shrinkage of the active material in negative plates. This does not show the real life on the fibre-clad cell because the positive plates were still in good conditions.

Larger capacity mentioned in the former part of the statement is also confirmed in TL 1 and

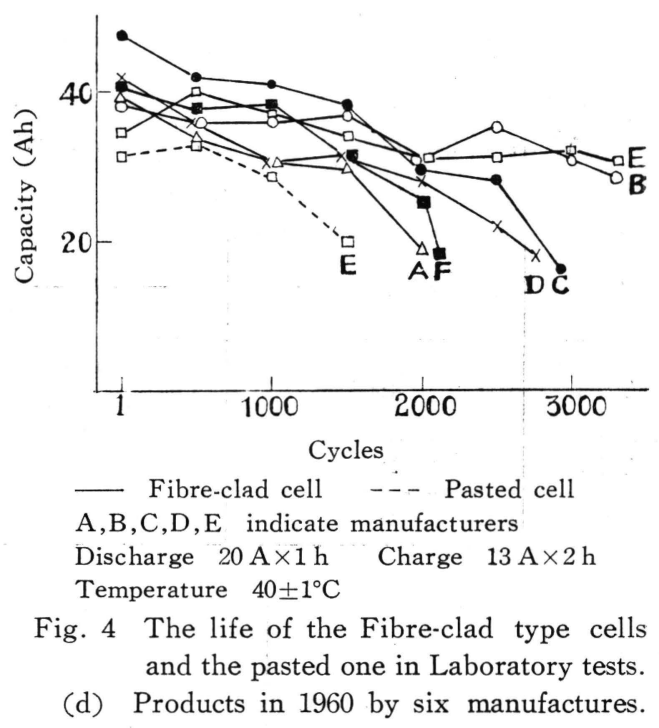

TL 4 when compared with the $5 \mathrm{~mm}$ pasted plate of the same dimensions.

For reaching conclusion on the matted and the braided tubes, further tests will be required because the life of cells is largely influenced by the skill of manufacturers on other factors.

\section{Service Life Test}

\subsection{Cells Used for Test}

Outline of the test reference cells is shown in Table 4. Each cell was assembled in the factory of JNR using the parts purchased from manu- 
facturers.

\subsection{Method of Service Tests}

Each test cell was installed on the express train, connected in series up to $24 \mathrm{~V}$, with the reference cells and commercially available cells combined. The voltage of the generator was kept in the range of 28 and $32 \mathrm{~V}(28 \mathrm{~V}$ in summer, $30 \mathrm{~V}$ in winter and $32 \mathrm{~V}$ in the severe cold). Some operating conditions of cells are shown in Table 5. The plates used for reference cells are the products of manufacturer $\mathrm{B}$, for which the long life is generally assured in the past and moreover, care was taken so that the side of each plate was covered in completely with a thin sheet of polyethylene. The capacity test with a discharge current of $64 \mathrm{~A}$ was periodically performed once a year on the cells taken off from the train. When the capacity of a cell dropped below the ampere-hours equivalent to $60 \%$ of the rated ampere-hours, the life test of this cell was regarded as being completed and thereafter the
Table 5 Running Section and the Use of Cells

\begin{tabular}{c|c|c}
\hline \hline Test & $\begin{array}{c}\text { The section by } \\
\text { train run }\end{array}$ & Operations of cell \\
\hline TS 1 & Tokyo-Osaka & $\begin{array}{l}\text { Cells are operated, as a rule, } \\
\text { from 1 to10 minutes with the } \\
\text { current of 40 A while the } \\
\text { car stops. Besides, total 1 } \\
\text { to 1.5 hours with the same } \\
\text { current are added before } \\
\text { start and after arrival. }\end{array}$ \\
TS 2 & Tokyo-Hiroshima & Hakodate-Nemuro \\
\hline
\end{tabular}

cell was dismantled for investigations.

\subsection{Results}

Each result of test is shown in Figs. 5 to 7 . In Fig. 5 the capacities of the two test cells B, $\mathrm{C}$ are both larger than that of the reference cells at the start, but the trend is reversed after a year with the exception of cell A. It is quite worthy of note that the test cells did not exhibit any longer life contrary to our expectation. Similar results are also noticed in Fig. 6 in spite of the test having been performed at comparatively low temperatures. In Fig. 7 the life of the test cell is seen undoubtedly to be

Table 4 Outline of Cells in Service Test

\begin{tabular}{|c|c|c|c|c|c|}
\hline \multirow{2}{*}{ Test } & \multirow{2}{*}{ Year of manufacture } & \multicolumn{2}{|l|}{ Test cells } & \multicolumn{2}{|c|}{ Reference cells } \\
\hline & & Construction & Manufacturer & Type & Manufacturer \\
\hline TS 1 & 1954 & $\begin{array}{l}\text { Element is inserted in the jar of } \\
\text { the same size as that of the }\end{array}$ & $\begin{array}{l}\text { A (matted) } \\
\text { B (matted) } \\
\text { C (braided) }\end{array}$ & TRE 16 & B \\
\hline TS 2 & 1954 & Number of the positive plate & $\mathrm{B}, \mathrm{C}$ & TRE 16 & B \\
\hline TS 3 & 1956 & is 10 . & B & TRA 12 & $\mathrm{~B}$ \\
\hline
\end{tabular}

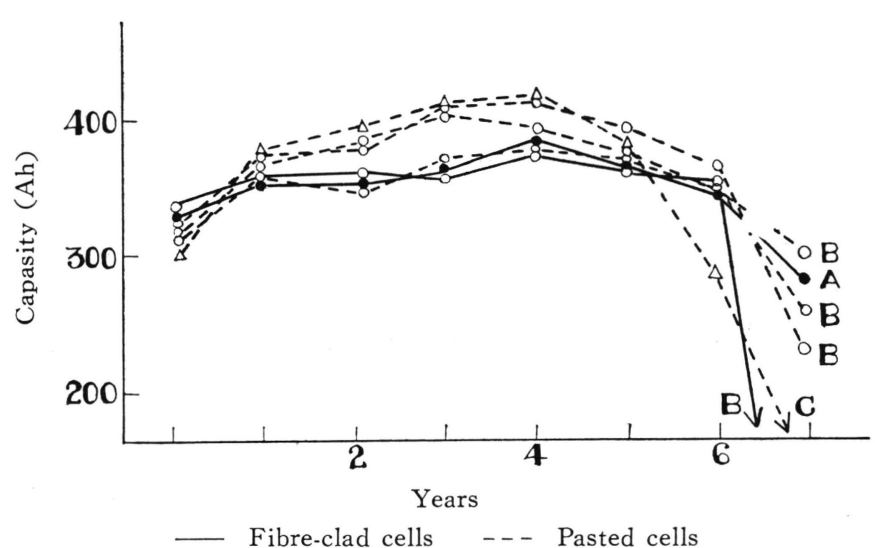

$\mathrm{A}, \mathrm{B}, \mathrm{C}$ indicate manufactures.

Fig. 5 The life of the fibre-clad type cells and the pasted one in the service tests for train-lighting.

(a) Express train between Tokyo and Osaka. 


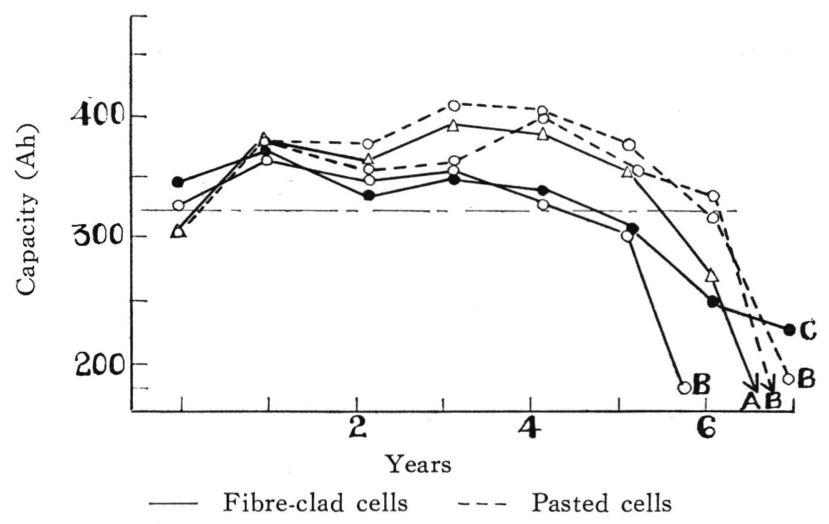

A, B,C indicate manufacturers.

Fig. 6 The life of the fibre-clad type cells and the pasted one in the service tests for train-lighting.

(b) Express train between Hakodate and Nemuro

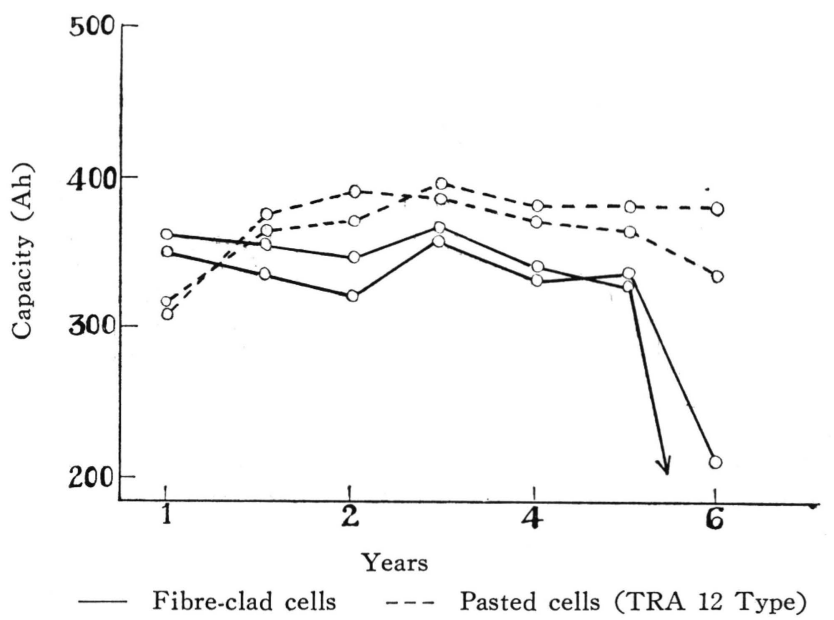

Fig. 7 The life of the fibre-clad type cell and the pasted one in the service tests for train-lighting.

(c) Express train between Tokyo and Hiroshima

shorter notwithstanding the larger capacity at the start. The results in this case leave some room to arouse sympathy to the manufacturer $B$ of the fibre-clad cell because a certain improvement on the reinforcement of sleeve from the chemical and physical aspects achieved by this manufacturer after this test can be recognized the large difference of life indicated between the results in TL 3 and in TL 4 . Together with these results, under somewhat different conditions, it may be concluded that the fibre-clad type cell has no advantage over the pasted cell in the use of train-lighting.
The reduction of the capacity difference between the two types of cells at the start is considered to be caused by the increased number of the pasted plates in a jar, namely, the increase of the whole surface area of the plates. The tendency of a comparatively little increase during the service noticed with the fibre-clad cell is considered to be due to the peculiarity of the sleeve which affects largely the volume change of the positive active materials. The tend. ency of the life of the fibre-clad type cell which was disappointing will be considered later with other data.

\subsection{Considerations}




\section{Considerations on the Life of the Fibre-clad Type Cell}

The relative length of life, test conditions and causes of failure investigated by dismantling the failed cells are summerized in Table 6 .

First of all, the long life of the fibre-clad type cell in laboratory tests should be considered in connection with the unusually short life of the pasted type cell which is failed by the deterioration of the positive active materials earlier than the case by other causes. As the cause of the deterioration above-mentioned, following three points are indicated: (1) discharge conditions (2) charge conditions (3) construction of elements.

The effects of the conditions of charge and discharge upon the shedding of positive active material were investigated in the past for the purpose of clarifying the mechanism of shedding $^{1 / 2)}$. Points necessary for consideration are summarized as follows. (i) Shedding takes place during discharge as well as charge. The amount of sediment at the bottom of the jar during discharge is 2.5 times larger than that during charge. ii) The shedding during discharge acceleratingly increases with the deepness of discharge and the progress of cycles of charge and discharge. iii) According to the relative effect of discharge to charge, the deterioration of the active material should occur more seriously than the degree indicated by the ratio of sediment in (i), because the discharge acts not only as the cause of direct shedding, but also as the latent cause of shedd ing by the loosening of the active material which takes place during the next charge. Further consideration should be made on these points as well as

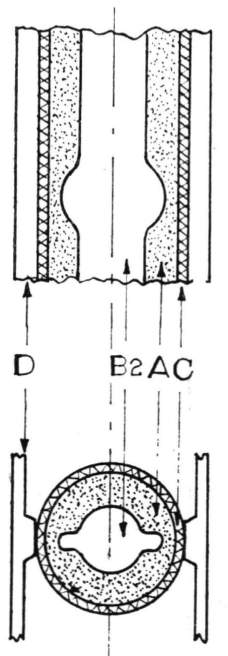

(a)

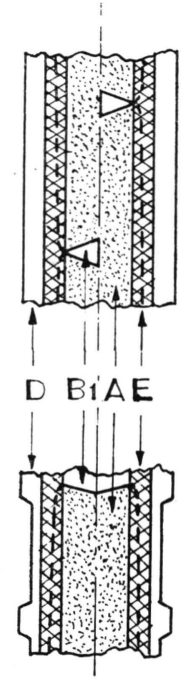

(b)
A Active material
C Sleeve
B Grid
D Separator
$\mathrm{B}_{2}$ Spin
E Glass mat

Fig. 8 Outline showing the construction of the fibre-clad cell and the pasted one.

Table 6 Summarized Data on the Life of Cell

\begin{tabular}{|c|c|c|c|c|}
\hline Cells & $\begin{array}{c}\text { Kinds of } \\
\text { test }\end{array}$ & $\begin{array}{l}\text { Relative length } \\
\text { of life }\end{array}$ & Test conditions & $\begin{array}{c}\text { The state of failed cells at the end } \\
\text { of life test }\end{array}$ \\
\hline \multirow[b]{2}{*}{$\begin{array}{l}\text { Fibre- } \\
\text { Clad }\end{array}$} & Laboratory & 1 & $\begin{array}{l}\text { Deep discharge } \\
\text { Charge by constant current } \\
\text { which is comparatively large }\end{array}$ & $\begin{array}{l}\text { Loss of active materials (sleeve split, escape } \\
\text { from the lower end of tube); corrosion and } \\
\text { crack of spin. }\end{array}$ \\
\hline & Service & & $\begin{array}{l}\text { Low discharge } \\
\text { Charge by constant voltage, } \\
\text { the current of which re- } \\
\text { markably decreases at the } \\
\text { end. }\end{array}$ & $\begin{array}{l}\text { Partial abnormal swelling in tubes } \\
\text { Loss of active materials (slight compared with } \\
\text { laboratory test), Corrosion and crack (heavy } \\
\text { compared with laboratory test) } \\
\text { Sulfation of netative plates. } \\
\text { Short circuits. }\end{array}$ \\
\hline \multirow[b]{2}{*}{ Paste } & Laboratory & $1-1$ & $\begin{array}{l}\text { Same with the above- } \\
\text { Laboratory }\end{array}$ & $\begin{array}{l}\text { Remarkable deterioration of active material. } \\
\text { Short circuit between the plates caused by the } \\
\text { above fact. }\end{array}$ \\
\hline & Service & & Same as the above-Service & $\begin{array}{l}\text { Deterioration of active material, Corrosion of } \\
\text { grid and crack of frame. } \\
\text { Short circuits. } \\
\text { Sulfation of negative plates. }\end{array}$ \\
\hline
\end{tabular}

Note : There is no quantitative relation between the life of laboratory and that of service test. 
on the construction of elements. The partial sections of the element of the pasted type cells are shown in Fig. 8(b). As is easily understood from this, the shedding does not so easily take place in the construction of elements because the glass mat in contact with the surface of the positive plate under pressure play a preventive role. However, the expansion of the active material toward the glass mat which takes place gradually during the cycle is unavoidable as shown by the dotted line in some parts of the glass mat, which leads to a decrease of the mutual incorporating power in lead peroxide. This causes a decrease of the capacity of plates on one hand and a short circuit between the plates on the other. This tendency increases with the deepness of discharge in the same way as mentioned in (ii). As the result, the short life of the pasted type cell takes place when discharge is deep in test cycles. In fibre-clad type cells, on the contrary, with its peculiar construction, the expansion of the active material can be prevented by the sleeve and it is kept as it was as shown in Fig. 8 (a). Consequently the escape of the active material through the sleeve does not become a serious problem for a considerably long period of time until other causes of failure appear, so far as the sleeve posseses the sufficient strength and the adequate size of network. This tendency does not change so much with the deepness of discharge. As the result, the life is long irrespective of discharge conditions.

According to these considerations, the short life of the pasted type cell for deep discharge cycles is attributed to the fact that the laboratory tests were performed under the condition unfavorable only to the pasted type cell in its early deterioration of the active material. The extreme short life of the pasted type cell in comparison with that of the fibre-clad one found in Fig. 2 is explained here for the first time by the fact that the test condition was selected particulary unfavorable for this type of cells. As compared with this fact, the effect of the capacity difference upon the life between the two types of cells at the start is negligible as easily understood by contrasting the tendency shown in Fig. 1 and Fig. 2.

On the other hand, the litttle difference in life between the two types of cells, which was observed when the discharge is not deep in cycles like the service tests described before, can be explained by the fact that tests were performed under the condition which is favorable to the pasted type cell as well as well as to the fibre-clad one. From these, it is concluded that the long life of the fibre-clad type cell hitherto believed to be universally true should be limited only to the conditions of deep discharge.

To confirm this conclusion, further tests were performed. Twelve cells of fibre-clad type were installed on a tractor operated in the stationyard with the same number of reference cells all connected in series to $48 \mathrm{~V}$. The discharge current roughly estimated in this use is $100 \mathrm{~A}$ at the start and $40 \mathrm{~A}$ while the tractor is running over a distance. This discharge repeated with intervals before recharge naturally lead cells to a deep discharge. The charge is made principally en bloc during the night while the tractor is free. The outline of cells is as follows: Test

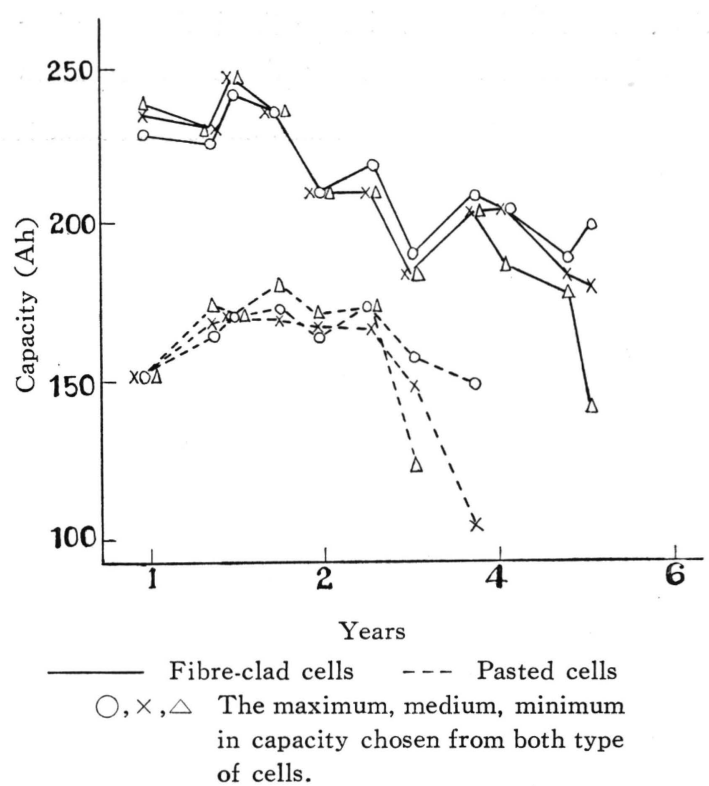

Fig. 9 The life of the fibre-clad type cells and the pasted one in the service test for a tractor. 
cell; $161 \mathrm{Ah}$ in $5 \mathrm{hr}$ rating capacity, 7 positive plates composed of 15 tubes with a diameter of $9.6 \mathrm{~mm}$. Reference cell ; the same rated capacity as that of test cell, 7 positive plate $5 \mathrm{~mm}$ in thickness, Kathanode construction with the " $Z$ " plates by manufacturer E. Specific gravity of the electrolyte was lowered from 1,280 to 1,250 after the 2nd year's capacity test.

Results are shown in Fig. 9. In these, each 3 of both types which represent minimum, medium and maximum in capacity after a period of use were chosen. The tendency recognized in the laboratory test TL 1 and TL 2 reappeared also in this service test as expected.

\section{Conclusion}

Putting the above mentioned data together, the fibre-clad type cell is evaluated as follows.

Large capacity of the cell of this type observed in many cases is found not universal. It depends upon the construction of the reference cell. Long life is also not universal. Its superiority can be recognized only for the use of deep discharge, not for that of low discharge. The usage of the fibre-clad type cell, therefore, comes to be limited only in the former condition. Indeed, it must be realized that further additional improvements by the manufacturers on this type of cell are necessary after the years of above tests on their new products. However, improvement in life for the use like trainlighting is still possible also open to the traditional pasted type.

In evaluation of this type cell for trainlighting, it should also be considered that the cost is about $30 \%$ higher than that of the pasted type cell. The cost of the fibre-clad type cell will be able to break even, if it can serve 30\% longer than the pasted one; and the question of its superiority to the latter will occur only when this is assured. Even in this stage the failure of the negative plates also comes in question. Still more, the relation between the two types of cell in above-mentioned cost does not seem to change in future in consideration of their manufacturing operations. For this reason, it may be difficult. to foretell that the fibre-clad type cell will take the place of the pasted type for uses of low discharge like train-lighting. On the other hand, this cell should be greatly recommended for the use of deep discharge like tractors or locomotives.

\section{Literature :}

1) M. Yokoyama, Denki-Kagaku 10, 29 (1943).

2) S. Hisano, J. Rail. Eng. Res. 10, No. 24, 15 (1953). 